\title{
Behind China Sport Industry Development: Football
}

\author{
Raul Syahrozi Demeiati Nur Kusumaningrum Hafid Adim Pradana \\ Departement of International Relations, University of Muhammadiyah Malang \\ Jl. Raya Tlogomas, No. 246, Malang, East Java, Indonesia 65144
}

\begin{abstract}
This paper studies and analyses the reasons why China paying attention to sport industry especially football. Basically, Chinese government see football as a pretty promising business field of the century. In otherside, China plans for a few next year is qualify as contestant of football world cup, hosting the football world cup and become the champion of the football world cup. As the real act to their national interest, China government issued some policies along with private group and all element pull the work together regarding to support the development of their football such as established the biggest football school in Guangzhou. The growth of sport industry per year in number obviously tempt government to generate more money from it. This research uses national interest concept and Mercantilism theory to analyse what drives China develop their sport industry, especially football.
\end{abstract}

Keywords: Football, Development, China Government, Sport Industry, National Interest Concept, Mercatilism, World Cup.

DOI: $10.7176 / J L P G / 81-04$

\section{Introduction}

The developments of global sport industry from years to years has shown a fairly complex positive impact from food, memorabilia stands at stadium, media rights and sponsorships. Global sports industry is growing faster than over all nations Gross Domestic Products $(G D P)$. At the same time media and sponsorship came as the main engine of sport industry growth. Sport and entertainment now seen as two side of the same coin and its increasingly staged together as the way to enhance overall experience and extend length of event (Clark, 2011). As the Forbes said "global sport industry worth to reach 73.5 by 2019 " and the number estimated will keep growing as the year goes on.

China government really sees the high number of revenue they can gain from sport industry, means sport as promising business industries. On 2016, the General Administration and National Bureau of Statistics stated the domestic sport industry reached 294.1 billion dollars, 11,1 percent up than previous year. "It is estimated by 2025 , the scale of the Chinese sports industry will be likely to reach the goal of 773.9 billion dollars" said the Huang Haiyan sport industry expert from Shanghai University ( Xin, 2018). Very serious desire from the Chinese government on sport industry tried to be described through national plan to build 100 towns dedicated as centres of sporting excellence for various disciplines in coming years.

The Chinese government really keen to develop the sports industry as much as possible as one of the economic barns and entertainment for their communities in the future. One of Chinese government efforts and hard work can be seen in the 2008 Beijing Olympics event where China successfully hosted and came out as the overall champion with the most gold acquisition (Saragih, 2012). The hard work is trying to be continued by the current Chinese government led by President Xi Jinping by intensifying the construction of several sports facilities and policies that are in line with the development of the domestic sports industry.

Nowadays, football is one of the most popular sports in the world and is growing in China. In advance, football is not too developed, the interest of the people of China is fairly low and more interested in playing other sports such as basketball, table tennis (Durnin, 2015). By society low's interest on football, the Chinese government seeks to improve the existing football climate with various measures and policies. Mr. Xi explained that China is will be one of the centers of world football in the future and that it seeks to be realized by hosting the football world cup, qualifying for the football world cup and becoming the world soccer champion (Hasdiansyah, 2017).

Despite it seems very difficult, China's efforts to revolutionize domestic football are likely will come with result someday. Transfer of top European players from top European leagues, fantastic funding from investors to domestic clubs, cooperation between the private sector and the government in the field of football to build the world's largest football academy as a concrete step in realizing their commitment to become one of the world football power in future.

Accordingly, the research problem of this paper is " why does Chinese government paying attention to sport industry, especially football?’”.

\section{Research Methodology}

The research in this paper uses library resources with qualitative data analysis of materials collected from 
various books, journals, the internet, and other related resources. The concept of national interest by K.J. Holsti is selected to analyse why does Chinese government paying attention to sport industryand what drives them to it. In otherside, the theory of mercantilism will investigate the main purpose beyond all hard work to revolutionize sport industry, especially football as the famous and most played sport in the world.

\section{The Chinese Sport Industry Backgrounds}

Nowadays, China named as one of developed countries and has transformed into a new world power. The achievement is gain since they adopt the reform and opening-up policy in 1978, China has experienced rapid economic and social development with growth rates averaging $10 \%$ over 30 years, which is the fastest, sustained expansion by a major economy in history (World Bank, 2016). Today China hold the first position as the highest population by 1,416,970,134 (World O Meter, 2018). Driven by modern lifestyle, rising the awareness of healthy lifestyle and the demand of sport equipment and entertainment seemed also to be growing fast. Proven by societies participation at sport and various events of sport that hosted in China (Liu, 2016).

Time after time, sport industry is emerging gradually and it keeps growing. Long time before, the professional sport in China was undeveloped, because sport was become the government prerogrative. Situation start to change on 1994, government set up the official football championship for professional footballer and it was confined. Soon since football championship was played and extended to basketball (Liu, 2017). Despite China go through economic rapid growth, financial stakes of the championship generated corruption, match fixing, illegal betting and bribing referee and players to influence the result of of game which is quickly tarnished the image of the championship (Liu, 2017).

On early 2000's, the level and reputation of China professional sport very low. Worst on 2005, the average game attendance at stadium down $60 \%$ from 24.000 viewer into 10.000 since Chinese football championship changed their name from "Chinese Super League" to "Chinese Serial A League" and league went without major sponsor. Disappointment regarding poor management by the government turned Chinese fans and business sponsor to international sport such English Premier league (EPL) and National Basketball Association (NBA).

Lately 2010's, the development of professional sport shown its enhancement which the number of stadium attendance and investor slow but surely rising (Durnin, 2015). Chinese government struggle and committed to restrore the professional sport by setting a number of policies for next. Based on press release, The State Council of the People's Republic of China announced national sports market should generate 1\% GDP (Gross Domestic Product) of the total growth by the end of 2020, in 2013 national sport market contribute $0,63 \%$ GDP (Gross Domestic Product) of the total growth (Sliwowski, 2017).

\section{Revenue Structure of Domestic Football}

In 2015, broadcasting right of team China were acquired by Ti'aoDongli sport media broadcasting for four years which is amounted to 70 million Yuan at the first year and its supposed to increase year by year until the end of contract (Yutang Sport \&O Diobhilin,2016). At the same year, Chinese Football Association (CFA) determine as set of standard of partnership deals for team China, presenting partner must pay minimum of 50 million Yuan, official sponsor 20 million Yuan, official supplier 10 million Yuan.

Amount of money that earned by team China through sponsorship and broadcasting revenue still can not compete with top five European league football federation, which is 80 million Euro was the lowest revenue generated by Spanish and Italian ootball federation in 2015 through broadcasting and sponsorship. In otherside, China only got a half of them, 43.5 million Euro in 2016 (Sliwowski, 2017).

Chinese Super League broadcasting fee entering new phase in 2016 after Ti'aoDongli agreed to paid 8 billion Yuan for CSL broadcasting right to next five years ( Xinhua (C), 2016 \& Ho, 2016). In addition, Chinese Super League secure 520 million Yuan from its ten sponsor and suppliers in 2016 with detail, Ping an Insurance paid 170 million Yuan, Nike, Ford, JD.com, Carlsberg, DHL, Redbull paid 250 million Yuan and two official supplier supported the league with 100 million Yuan (Sliwowski, 2017).

Revenue also gained through match day, within China has plenty of room to maximize in this domain. The average of full stadium capacity of Chinese football club was higher than four of the top five European league and Major League Soccer and Chinese club still struggle to fill some blank stadium seat. But the problem is, ticket price for football match day is still too low to gained revenue as much as possible (Bland \& Clover, 2016). In 2013, season ticket per gameand the individual match ticket price, a Chinese Super League ticket cost 58 Yuan or 7.9 Euro (Sliwowski, 2017).In 2016, the Chinese Super League totalattendance at stadium is 5,798,880 people, with an average 24,162 spectators per game. In 2016, Chinese Super League generated 336 million Yuan / 45.7 million Euro from match day revenue, compared to top five European league and Major League Soccer is still far behind.

International comptetion also can be source of additional revenue for domestic football club and national team. Asian Football Champions League the most prestigious football competition among Asian football clubs. Chinese football club shown good performance on Asian Football Champions League in recent years like 
Guangzhou Evergrande, Shanghai SIPG, and Shandon Luneng. The winner of Asian Football Champions League will revieve 3.1 million Euro in 2016, twice higher than 2015 which only 1.6 million Euro and runner up will receive 1.4 million Euro as the prize (Soccer 24(A), 2017). Amount of money for the Asian Football Champions League is eleven time less than their counterpart in Europe as the winner of UEFA Champions League accumulate a revenue of 35.5 million Euro after group stage elimination to the victory.

Chinese National Football team also could increase their revenue by participating in international competition, Football World Cup. Just in case, Chinese National football team qualified to play on FIFA World Cup 2014 so they can add 7.2 million Euro to national team revenue and the number of money are expected to be added to the next FIFA World Cup 2018 (Sliwowski, 2017). Somehow, Chinese National team can not earn money every years from FIFA World Cup, because the event held every 4 years. On the other hand, Chinese national team able to generate additional income from Asian Football Championship, but there is no prize for a moment (FOX Sport, 2015).

\section{World Football Power Plan}

On recent decade, China defined has huge football fan bases despite football was not the most popular sport in country but, $31 \%$ of Chinese urban population aged from sixteen to fifty-nine are interested of football (Nielsen,2016). The most popular sport is basketball (40\%), table tennis (37\%), badminton (36\%) and swimming (34\%), whilst football is growing steadly in recent 6 years since the government and private group a lot of hardwork to develop the national football (Sliwowski, 2017). Based on FIFA's data, China has become one of the connoisseurs of the 4th annual event (World Cup) with the most spectators on television. On FIFA World Cup 2006, the number of China viewer was estimated around one-fifth of the total spectators. The next event on 2010, China came again as the highest spectator with respectively 328.7 million spectators. The number of spectators was decrease on FIFA World Cup 2014 due the less favourable time zone of compared by South Africa but still got the highest number with 252.2 million (Kantar Sport, 2010 \& Kantar Media, 2014). Regarding the fans that keeps growing year by year, Chinese Government, private groups and all elements all involved in football develepment trying to arrange perfect plan like issuing policies related to sport and implenting compatible strategy due the ambition become world football superpower in the future.

\section{Government Strategy}

$\mathrm{Xi}$ Jinping as the president and general manager of Chinese Communist party known as football, which is Chinese society can have strong count on him for their national football development. Mr. Xi want to turn Chinese football become world football superpower by 2050 and he is pushing government to participate on that project (BBC, 2016). October 2014, Chinese state council released a proposal about "Accelerating the Development of the Sports Industry and Sports Consumption" and the level of sport development including football has been upgraded into national strategy level (Yutang, 2017). At some points, its stated 3 steps to reform the national football and building 20.000 football school as the way to develop national football into world football superpower. Afterwards, Xi Jinping compile and ordered the China's Highest governmental decision-making body on sport matters to define new reform plan on national football development and will be addressed to all bodies that associated with football developments ( Meyer, 2015 \& Wilson, 2016).

Chinese Government also has established three stages of national development in medium to long term:

- 20.000 football school, 70.000 football fields, 30-50 million of primary and secondary students are playing football before 2020 .

- 50.000 football school, male Chinese football team became the best team in Asia, Female team established as worldclass team before 2030 .

- First rank on top 20 FIFA ranking for male football team, already hosted FIFA World Cup, won the World Cup (Leite, 2017)

Government also made some initiatives like reform governing body that in charge for football development, reforming and improving football club's operation, develop football at the grassroot level, improve professional training and talent development and encourage investor to invest on football industry (Durnin, 2015).

\section{Partnership}

Along with hard effort by government to develop national football, partnership with some experts will help China to push forward their football development to the next level. In 2009, Chinese Football Association and Chinese Ministry of Education starting partnership with the British Council and English Premier League, which is aimed to train over six hundred physical education teacher in more than five hundred school that located in nine cities (British Council, 2015). The partnership being renewed on 2013 purposed to train more than two hundred Chinese football referee.

The Chinese Football Association also build partnership with Belgium Football Association by 2016, intended to develop football by having collaboration between both country on different levels, visits, coach 
development and friendly match in different ages (GB Times, 2016). On the same year, Mr. XI Jinping negotiate Angela Merkel to establish cooperation between Chinese Football Association and German Football Association to support Chinese football development. As a return, German companies and football team will get easier access to broadcast their football in China (Jing, 2016 \& Ahmed, 2016). Some Chinese clubs also made partnership with some European clubs like Real Madrid, FC Barcelona, AC Milan and Arsenal in term to develop football academies in China (Jingxi, 2017).

\section{Private Group Support}

Turning China into world football superpower exactly need collective work, means private group have to participate to help government actualizing the ambition. Private group has a vital role on Chinese football development beside government as a legal body who comes with regulation about football development. In 2011, Wanda Group grant 68 million Euro to Chinese Football Association as the real act to help government to improve youth development and find a new coach for national team (Zhe\&Xiangfeng, 2011 \& Wanda Group, 2017). Back on 2009 Evergrande Real Estate Group became the first the big company who was invested in Chinese football which followed by another companies in the some way (Sliwowski, 2017). Club acquisition by private company shows very big change in term of revenue that was increased in very short time and the investor can bring their personal funds and attract more sponsor to work side by side.

Guangzhou Evergrande as the instance seized the highest revenue in Chinese Super League as the club was taken over by Evergrande Real Estate Group and Alibaba (Sliwowski, 2017). Aside from financial support by the private groups, those investor give a positive impact on club performance result. Guangzhou Evergrandebecoming the Asian Champions League title holder on 2015 after being acquired by the private company after the next three years, previously the club play for Chinese Second Division league (The Economist, 2011).

As another effort to develop domestic football, Chinese enterpreuner not only invest in domestic club but also in foreign clubs like AC Milan, Inter Milan and Atletico Madrid. Those action aims to help football development of China as the agreement of football player exchange which will support young Chinese football player to raise their skill by training in Europe such as Suning and Wanda Group who bought stakes in Inter Milan and Atletico Madrid are welcome to young Chinese player to the club (Sha, 2016). The Chinese investor also want to expand the importance of China role at highest level of football like becoming FIFA's partner which could be strategic way to host the international sport event like FIFA World Cup (Sha, 2016).

\section{Conclusion}

The development of global sports industry from year to year showed a positive impact and became an opportunity for all countries in the world, including China. On top of that, the growth of Gross Domestic Product (GPD) sport industry has continued to grow steadily in recent years and is higher than all countries Gross Domestic Product (GPD) in the world. A few years before, Chinese government only focus on economic and trade industry and seemed to be expanded this recent year to sport industry to gain more revenue.

Based on the concept of national interest from the K.J. Holsti, the development of the sports industry specifically carried out by china is one way to improve and improve their economy, where things are classified into an objective Middle-range point. In other side, the Mercantilism theory states that a strong state is built from a strong economy. as explained earlier, the growth of a fairly massive sports industry was seen by China as an opportunity to strengthen their economy to build powerfull country.

China Dreams to be of new world football superpower in the future is trying to be realized by some real actions. It is start with basic thing like some policies that related to sport industry issued by the government, support from the private sector as well as collaborations established by the government and other countries. however, all the elements should involved and have to go hand in hand to get the maximum benefit from the sports industry and reach their dreams as a new world football superpower in future.

\section{REFERENCE}

AHMED, Murad, 2016. Financial Times - China taps German knowhow in pursuit of football goals. (Accessed 20.06.2018). Available at : https://www.ft.com/content/11b6d014-b25e-11e6-a37c-f4a01f1b0fa1

BBC, 2016. China aims to become football superpower "by 2050”. (Accessed 28.02.2017). Available at : http://www.bbc.com/news/world-asia-china-36015657

BLAND, Ben \& CLOVER, Charles, 2016. Financial Times - Chinese Football: More than a game. (Accessed 19.07.2018). Available at : https://www.ft.com/content/3a4b5e92-e5e4-11e5-bc31-138df2ae9ee6

BRITISH COUNCIL, 2013. British Council - Football project aims to reach 1.2M Chinese students by 2016. (Accessed 20.06.2018). Available at: https://www.britishcouncil.org/organisation/press/football-projectaims-reach-12mchinese-students-2016

CLOVER, Charles, 2016. Financial Times - TV rights deal confirms China football's rise. (Accessed 
03.04.2017). Available at : https://www.ft.com/content/7e00e7aa-da14-11e5-98fd-06d75973fe09

D. CLARK, Julie. 2011. Changing the Game: outlook for the global sport market. (Accessed 17.11.18). Available at : https://www.pwc.com/gx/en/hospitality-leisure/pdf/changing-the-game-outlook-for-theglobal-sports-market-to-2015.pdf

DURNIN, Matt 2015, China's football market: Development from grass roots to elite level, .(Accessed 29.03.2017)https://www.events.trade.gov.uk/media.viewer/uploads/pdf/ekp_file_0_1_2_mattdurnin_thursday_day-13_week3-ifb2016_1467800418.pdf

FIFA (B), 2017. FIFA .com- 2002 FIFA World Cup Korea/Japan.(Accessed 13.09.2018). Available at : http://www.fifa.com/worldcup/archive/koreajapan2002/matches/index.html

FORBES, 2017. Forbes - The world's most powerful people. (Accessed 28.08.201). Available at: https://www.forbes.com/profile/xi-jinping/

GB TIMES, 2016. GB Times - Chinese and Belgian Football Associations sign development deal. (Accessed 08.10.2018). Available at: http://gbtimes.com/china/chinese-and-belgian-football-associations-signdevelopmentdeal

GIBSON, Owen, 2016. The Guardian - The great windfall of China: a football revolution that may lead to World Cup. (Accessed 28.04.2018). Available at : https://www.theguardian.com/football/blog/2016/feb/06/china-football-revolution-worldcup

HASDIANSYAH, Gunanda, 2017, Sepak Bola Tiongkok:darimana datangnya Uang-uang klub Tiongkok?.(Accessed 21.04.2017) Available at:, http://panditfootball.com/cerita/207373//170115/sepakbola-tiongkok-dari-mana-datangnya-uang-uang-klubtiongkok-bagian-1

HEITNER, Darren.2015. Sport Industry To Reach \$73.5 Billion By 2019. (Accessed 11.11.2018) Available at: https://www.forbes.com/sites/darrenheitner/2015/10/19/sports-industry-to-reach-73-5-billion-by2019/\#37a0ff811b4b

HO, Jane, 2015. Forbes - Li Ruigang's China Media Capital To Pay $\$ 1.3$ Billion For Soccer League Broadcast Rights. (Accessed 23.10.2018). Available at : https://www.forbes.com/sites/janeho/2015/11/14/li-ruigangschina-media-capital-to-pay-1-3-billion-for-soccer-league-broadcast-rights/\#7fb3f1611 dff

JING, Fu, 2016. China Daily - German football coaches to train in China's schools. (Accessed 20.07.2018). Available at: http://www.chinadaily.com.cn/sports/2016-11/26/content_27492250.htm

JUNIOR, Leite \& Rodrigues, 20017. The Chinese Football Development Plan: Soft Power and National Identity. (Accessed 11.10.2018) Available at: https://www.researchgate.net/publication/321113466_THE_CHINESE_FOOTBALL_DEVELOPMENT_P LAN_SOFT_POWER_AND_NATIONAL_IDENTITY

LIU, Dongfeng, Michel Desbordes, James J. Zhang. 2017. Sport bussiness in China: Current State and Prospect.(Accessed 18.10.2018) Available at: https://www.researchgate.net/publication/312155184_Sport_Business_in_China_Current_State_and_Prospe ct

MEYER, Eric, 2015. Forbes - Beijing Resolves To Breathe New Life Into Soccer. (Accessed 20.03.2018). Available at: https://www.forbes.com/sites/ericrmeyer/2015/03/15/soccer-is-chineseafterall/\#570964196516

NIELSEN, 2016. China and Football - World sport's newest superpower. (Accessed 12.07.2018). Available at : http://www.nielsen.com/content/dam/corporate/us/en/reports-downloads/2016-reports/china-sportsbusiness-football-report.pdf

PANDIT FOOTBALL INDONESIA, Rencana Besar China untuk Menguasai Sepakbola Dunia.(Accessed 21.04.2018). Available at: https://sport.detik.com/aboutthegame/pandit/d-3393060/rencana-besar-chinauntuk-menguasai-sepakbola-dunia

PORTEOUS (A), James, 2016. South China Morning Post - How Alibaba aims to transform China's sports market - and help bring the World Cup to the country. (Accessed 20.03.2017). Available at : http:/www.scmp.com/sport/china/article/1908849/how-alibaba-aims-transform-chinassports-market-andhelp-bring-world-cup

PUTRATAMA, M. Arby Rahmat, 2016, Ambisi Sepak Bola China Juara Piala Dunia, CNN Indonesia.(Accessed 29.04.2017) available at: http://www.cnnindonesia.com/olahraga/20160203205249149-108715/ambisi-sepak-bola-china-juara-piala-dunia/

SARAGIH, Simon, 2012, Jangan Lupakan kehebatan Presiden hu Jintao. (Accessed 24.04.2017) Available at:http://internasional.kompas.com/read/2012/11/08/09440820/Jangan.Lupakan.Kehebatan.Presiden.Hu.Jint ao

SHA, Liu, 2016. CKGSB Knowledge - Why Chinese companies are investing in football clubs overseas. (Accessed 28.04.2018). Available at : http://knowledge.ckgsb.edu.cn/2016/09/26/sports/chinese-companiesinvestingfootball-clubs/ 
SLIWOWSKI, Nicolas, 2017, Is China the New Land of Football? International Business Management. (Accessed 17.07.2017) Available at: https://doc.rero.ch/record/306001/files/TDIBM_Sliwowski_Nicolas.pdf

SOCCER 24 (A), 2017. Soccer 24 - AFC Champions League 2016.(Accessed 19.04.2018). Available at :

http://www.soccer24.com/asia/afc-champions-league-2016/?t=tb02PVyg\&ts=lz40AC66

SPORTS SOHU, 2016. Sports Sohu - Exculsive: 2016 Super League Business Value Report. (Accessed 04.04.2018). Available at : http://sports.sohu.com/20161201/n474643063.shtml

THE ECONOMIST, 2011. The Economist-Little Red Card. (Accessed 13.06.2018). Available at :

http://www.economist.com/node/21541716

THE WORLD BANK (B), 2017. The World Bank - GDP growth (annual \%). (Accessed 17.04.2017). Available at : http://data.worldbank.org/indicator/NY.GDP.MKTP.KD.ZG?locations $=\mathrm{CN}$

TSUCHIYAMA, Ray, 2010. Forbes - Why China isn't at the World Cup. (Accessed 13.08.2018). Available at : https://www.forbes.com/sites/china/2010/06/17/why-china-isnt-at-the-worldcup/\#d9244bb15632

WAN, William, 2015. Independent - China's Xi Jinping loves football so much he's put it on the national curriculum - but can he secure the World Cup?. (Accessed 28.02.2018). Available at :

http://www.independent.co.uk/news/world/asia/chinas-xi-jinping-loves-football-somuch-hes-put-it-on-thenational-curriculum-but-can-he-secure-the-10071110.html

WANDA GROUP, 2017. Wanda Group - Corporate Profile. (Accessed 08.05.2018). Available at :

https://www.wanda-group.com/corporate/

WANG, Yue, 2016. Forbes - Chinese billionaires invest in football: is it worth it?. (Accessed 28.06.2018). Available at: https://www.forbes.com/sites/ywang/2016/02/04/chinese-billionaires-invest-in-footballis-itworth-it/\#48aa5fa1ec83

WILD EAST FOOTBALL, 2015. Twitter - Chinese Super League total TV viewership for 2015 season - 400 million. Up over 50\% on last year's 267 million. (Accessed 17.03.2018). Available at : https://twitter.com/wildeastfootbal/status/662434223052066816

WILSON, Cameron, 2016. Wild East Football - Read Chinese football's 50-point reform plan in full exclusive translation. (Accessed 18.03.2017). Available at : https://wildeastfootball.net/2016/02/readchinese-footballs-50-point-reform-plan-in-fullexclusive-translation/

World O Meter, 2018. China Population 2018. (Accessed 12.10.2018). Available at: http://www.worldometers.info/world-population/chinapopulation/? hstc $=172477884 . \mathrm{e} 766 \mathrm{fa} 1 \mathrm{fa} 02 \mathrm{bf} 22 \mathrm{faeff} 272 \mathrm{db} 118 \mathrm{f} 2 \mathrm{dd} .1528243200094 .1528243200095 .1528$ $243200096.1 \&$ hssc $=172477884.1 .1528243200097 \&$ hsfp $=1773666937$

Xin, Zhou. 2018. China's sports industry reached $\$ 294$ billion in 2016. (Accessed 10.11.2018) Available at : http://www.xinhuanet.com/english/2018-01/13/c_136893470.htm

XINHUA (A), 2016. China Daily Europe - Sports industry, next gold mine of Chinese economy. (Accessed 17.09.2018). Available at : http://europe.chinadaily.com.cn/business/2016-04/02/content_24253919.htm

XINHUA (D), 2016. The State Council The people's republic of China-Chinese sports industry aims to reach $\$ 460 b n$ in 5-year plan. (Accessed 28.01.2018). Available at : http://english.gov.cn/state_council/ministries/2016/05/05/content_281475342468190.htm

Ye, Josh. 2017. China's sport sector could be the next big growth market.(Accessed 20.10.2018). Available at: https://www.scmp.com/business/investor-relations/ipo-quote-profile/article/2104342/china-sports-sectorcould-be-next-big

YUTANG SPORTS, 2015. Yutang sports - 2014/15 Barclays Premier League Chinese TV Market Report.(Accessed 17.08.2018). Available at : http://en.ytsports.cn/news-1241.html

ZHE, Tang, XIANGFENG, Chen, 2011. China Daily - A changing game for soccer in China. (Accessed 20.09.2018). Available at : http://www.chinadaily.com.cn/sports/2011-07/06/content_12842011.htm 